\title{
O livro “Direitos das mulheres e injustiça dos homens” de Nísia Floresta: literatura, mulheres e o Brasil do século XIX
}

\section{The book “Direitos das mulheres $e$ injustiça dos homens” (Women's Rights and Men's Injustice) by Nísia Floresta: literature, women and $19^{\text {th }}$ century Brazil}

Isabela Candeloro CAMPOI*

Resumo: O livro Direitos das mulheres e injustiça dos homens foi publicado por Dionísia Gonçalves Pinto (1810-1885), mais conhecida como Nísia Floresta, em 1832. Tal obra foi considerada uma tradução livre de A Vindication of the rights of woman de Mary Wollstonecraft (1759-1797), autora inglesa que se tornou o principal nome em defesa dos direitos das mulheres no século XIX. No entanto, tratava-se da tradução de Woman not inferior to man de Mary Wortley Montagu (1689-1762). O artigo apresentado contextualiza o livro de Wollstonecraft no período, enfoca a trajetória da autora brasileira e a influência do Positivismo na sua obra, principalmente no que tange ao papel social das mulheres.

Palavras-chave: Nísia Floresta. Brasil Imperial. Século XIX. Mary Wollstonecraft. Positivismo. Mulheres de elite. Educação feminina.

Abstract: The book Direitos das Mulheres e Injustiça dos Homens (Women's Rights and Men's Injustice) was published by Dionisia Goncalves Pinto (1810 -1885) in 1832. She was more popularly known as Nisia Floresta. This book was considered to be a loose translation of $A$ Vindication of the Rights of Woman by Mary Wollstonecraft (1759-1797), an English author who became a leading figure in women's rights during the 19th century. However, it actually was a translation of Woman not Inferior to Man by Mary Wortley Montagu (1689-1762). This paper contextualizes Wollstonecraft's book from that period and focuses on the biographical aspects of

\footnotetext{
* Professora Doutora do curso de Licenciatura em História da UNESPAR - Universidade Estadual do Paraná, campus de Paranavaí - Av. Gabriel Esperidião, s/nº, CEP 87.703-000, Paranavaí, Paraná, Brasil, e pesquisadora associada ao NUPEHC-UFF, Núcleo de Pesquisas em História Cultural da Universidade Federal Fluminense. O artigo é desdobramento da pesquisa intitulada "O movimento transatlântico dos direitos das mulheres e conceitos educacionais no século XIX: a alemã Mathilde Franziska Anneke e a brasileira Nísia Floresta”, desenvolvida em estágio Pós-doutoral no Instituto de Estudos Latino Americanos da Universidade Livre de Berlin, Alemanha, sob supervisão do Professor Dr. Stefan Rinke e com apoio da CAPES (Coordenação de Aperfeiçoamento de Pessoal de Nível Superior) entre maio de 2009 e maio de 2010. E-mail: belacampoi@hotmail.com
} 
O livro "Direitos das mulheres e injustiça dos homens" de Nísia Floresta: literatura, mulheres e o Brasil do século XIX

the Brazilian author and the influence of Positivism on her work, especially concerning the role of women in society.

Keywords: Nisia Floresta. Imperial Brazil. $19^{\text {th }}$ century. Mary Wollstonecraft. Positivism. Elite women. Women's education.

\footnotetext{
"Por que [os homens] se interessam em nos separar das ciências a que temos tanto direito como eles, senão pelo temor de que partilhemos com eles, ou mesmo os excedamos na administração dos cargos públicos, que quase sempre tão vergonhosamente desempenham?”

(Nísia Floresta Brasileira Augusta em Direitos das mulheres e injustiça dos homens, 1832).
}

Se por um lado a Revolução Francesa significou a derrubada do Antigo Regime, o acesso da burguesia ao poder e o ensejo do debate sobre cidadania e democracia, por outro, negou participação política às mulheres.

Figura importante no conturbado contexto revolucionário, Olympe de Gouges (1748-1793) era membro da Sociedade das Republicanas Revolucionárias, entidade ligada aos girondinos. Em 1791, ela lançou a Declaração dos direitos da mulher e da cidadã em clara alusão à versão 'masculina' de 1789, documento que se tornou universalmente reconhecido como fundador dos modernos direitos à liberdade e à igualdade. Entretanto, fundamentou a construção concreta e não linear de um modelo de cidadania que adentrou o século seguinte e do qual as mulheres permaneceram por muito tempo excluídas (BONACCHI; GROPPI, 1995).

Durante o chamado período do Terror, Olympe de Gouges pagou seu atrevimento com a própria vida: foi guilhotinada, em 1793, por ter ousado reivindicar participação feminina nos primórdios de um sistema político que ainda se desenvolvia, mas que negou o direito de cidadania às mulheres. Na fase das incipientes democracias as mulheres não seriam cidadãs.

Naquela conjuntura foi publicado na Grã-Bretanha o livro que se tornou, no decorrer do século XIX, a principal obra tratando dos direitos das mulheres: A Vindication of the rights of woman, da inglesa Mary Godwin Wollstonecraft (1759-1797), mãe da célebre autora de Frankenstein, Mary Sheley. A primeira edição é de 1792 e foi dedicada ao controverso estadista francês, Talleyrand (1754-1838), que tinha posicionamentos retrógrados quanto à educação 
feminina e à emancipação das mulheres. As formas de participação social das mulheres foram debatidas no século das Luzes, sobretudo durante os anos que se seguiram à Revolução Francesa.

A concepção de que o campo da razão era privilégio dos homens, criando certa noção de hegemonia do masculino na área das ciências, foi um fenômeno do século das Luzes. Os filósofos iluministas teorizaram sobre as qualidades características de cada sexo, estabelecendo papéis, lugares e posturas de gênero que confinavam as mulheres ao âmbito privado. As diferenças biológicas serviam para justificar sua inferioridade social; da análise do plano físico (com as diferenças genéticas e sexuais) julgavam-se as faculdades intelectuais das mulheres.

Assim, naquele contexto, o livro de Wollstonecraft fazia coro ao discurso favorável às mulheres, mostrando que o debate sobre as expectativas sociais femininas ultrapassou as fronteiras nacionais e também atravessou o Atlântico. A versão em língua alemã de Vindication foi traduzida por Henriette Herz, famosa pelo salão literário que mantinha em Berlim na virada dos séculos XVIII-XIX. (DIETHE, 1998, p.23). Do outro lado do Atlântico a escritora alemã Mathilde Anneke, exilada nos EUA por ter participado dos movimentos de 1848, escrevia na imprensa sobre literatura e política, além de longos artigos jornalísticos sobre mulheres importantes, contribuindo para a divulgação do nome de Wollstonecraft na América do Norte (PIEPKE, 2006, p. 74).

No mesmo ano da publicação alemã de Vindication, 1832, saía em Pernambuco o que se acreditava ser uma tradução livre do francês para o português. Foram publicadas mais duas edições no Brasil: Porto Alegre (1833) e Rio de Janeiro (1839). Foi graças ao trabalho de Constância Lima Duarte que o texto nos chegou às mãos, já que em suas pesquisas de doutorado essa professora localizou um exemplar e, então, uma nova edição foi publicada em 1989, 150 anos depois da última publicação.

Direitos das mulheres e injustiça dos homens foi o título dado ao livro brasileiro, publicado sob o pseudônimo de Nísia Floresta Brasileira Augusta (1810-1885), escritora incipiente que ligou o nome da inglesa Wollstonecraft às vozes em defesa dos direitos das mulheres no decorrer do século XIX.

No entanto, conforme apurou a pesquisadora em literatura Maria Lúcia Garcia PallaresBurke (1996), apesar de Nísia Floresta afirmar que seu texto fosse uma tradução livre do Vindication de Mary Wollstonecraft, a publicação brasileira era na verdade uma tradução do livro de Sophie, pseudônimo de Mary Wortley Montagu (1689-1762), que escreveu Woman not inferior to man, em 1739. Montagu, por sua vez, inspirou-se (chegando até a plagiar certos trechos) no livro De l'egalité des deux sexes, de François Poulan de La Barre, publicado em 1673. Polemizando a respeito, Pallares-Burke chama a atenção para a prática comum do plágio no contexto literário do século XVIII. Independentemente da verdadeira autoria do livro traduzido e publicado no Brasil, é 
O livro "Direitos das mulheres e injustiça dos homens" de Nísia Floresta: literatura, mulheres e o Brasil do século XIX

certo que as publicações de Nísia Floresta contribuíram para que o nome de Mary Wollstonecraft fosse identificado com a defesa dos direitos das mulheres.

Evidência disso está no romance A moreninha, de Joaquim Manuel de Macedo, publicado em 1844 e considerado o livro inaugural do romantismo brasileiro. Carolina, a protagonista, havia lido Mary de Wollstonecraft (sic), e, em tom de zombaria, o personagem Augusto irritou a jovem quando lhe solicitou "comenda para quando fosse Ministra de Estado, e a patente de cirurgião do exército, no caso de chegar a ser general.” (MACEDO, s.d., p.48). E foi no âmbito do relacionamento entre os dois personagens românticos, em meio à descoberta amorosa, que o nome de Wollstonecraft apareceu. O vínculo da autora inglesa com a defesa dos direitos das mulheres (e a fala de Augusto é uma evidência disso) leva a crer que os leitores poderiam entender o que liam (TELLES, 1997, p. 407).

De fato, o livro publicado por Nísia Floresta provocou a reflexão sobre o status social das mulheres, já que defendia a participação feminina em postos de comando. Em uma sociedade patriarcal, escravocrata e recém-saída da condição de colônia, Nísia Floresta foi mulher incomum, atuante e de certa forma 'desajustada' se forem levadas em conta as expectativas que a sociedade brasileira tinha em relação às mulheres do seu tempo, afinal, a valorização intelectual do gênero feminino inexistia. Como foi a trajetória dessa autora brasileira?

\section{A autora brasileira e seu tempo}

Dionísia Gonçalves Pinto, mais conhecida como Nísia Floresta, estreou como escritora em 1831 no jornal Espelho das Brasileiras, de Pernambuco. Desde as primeiras publicações ela tratou da condição feminina e também por isso é considerada precursora do feminismo no Brasil (DUARTE, 2005).

Nísia Floresta nasceu no Rio Grande do Norte e seu pai, o advogado Dionísio Gonçalves Pinto Lisboa, era um português liberal casado com uma jovem viúva brasileira. Como era costume das famílias da elite nordestina, Nísia Floresta casou-se aos 13 anos de idade com o proprietário de terras Manuel Alexandre Seabra de Melo. Entretanto, e é bastante provável que o casamento tenha sido arranjado e infeliz, em poucos meses ela retornou (e foi aceita) na casa dos pais.

Uma evidência da personalidade progressista do pai de Nísia Floresta pode ser encontrada no episódio relatado por Henry Koster em seu livro publicado originalmente em Londres, em 1816. O viajante inglês refere-se ao encontro que teve com Dionísio, que o ajudou na compra de um 
cavalo. Ele descreveu a bela paisagem da região onde a família de Nísia Floresta morava e, convidado pelo anfitrião, Koster relatou:

\begin{abstract}
Senhor Dionísio apresentou-me a sua mulher. Ele é português e ela brasileira. Tem uma pequena propriedade no vale, que me pareceu prosperamente colocada. [...] Jantei à moda brasileira, numa mesa colocada a seis polegadas do solo, ao redor da qual nos sentamos, ou melhor, nos deitamos, sobre as esteiras. Não havia garfos e as facas, em número de duas ou três, eram destinadas a cortar unicamente os maiores pedaços de carne. Os dedos deviam fazer o resto. (KOSTER, 1942, p. 104105).
\end{abstract}

Além de ser um relato rico em informações sobre os costumes dos brasileiros do século XIX, o fato do pai de Nísia Floresta ter apresentado a esposa e o recebido em sua casa, sugere uma atitude incomum, já que, de modo, geral os viajantes estrangeiros referem-se às mulheres brancas como reclusas e longe de olhares estranhos (LEITE, 1984). Naquela ocasião, a pequena Nísia contava com apenas alguns meses de vida.

Na primeira metade do século XIX, os conflitos pela Independência sacudiam toda a América Latina e, de modo efetivo, os movimentos separatistas e republicanos assolaram o nordeste em 1817 e 1824, com as chamadas Revolução Pernambucana e Confederação do Equador, respectivamente. Recife era, naquela conjuntura, o mais importante centro de impressão e de edição do país, condição que era causa e consequência da divulgação das ideias que impulsionavam os movimentos contestatórios. Certa dose de antilusitanismo obrigou a família de Nísia Floresta a se deslocar em diversas ocasiões entre as províncias de Pernambuco e Rio Grande do Norte.

Em 1824, a família então se estabeleceu em Olinda, onde Dionísio atuava como advogado. Em suas notas biográficas, Nísia Floresta escreveu que seu pai fora morto em uma emboscada nos arredores de Recife, em 1828: "Esse advogado, que fizera triunfar o direito de seu pobre cliente, alvo da injustiça atroz de um tal tirano, caiu de improviso sob os golpes de assassinos pagos por ele.” (FLORESTA, 2001, p.52) ${ }^{1}$. Conforme afirma Constância Lima Duarte, o crime foi motivado por conta de uma causa judicial ganha contra um integrante da poderosa família Cavalcanti (1995, p.21).

Essa mesma autora sugere que Nísia Floresta tenha recebido as primeiras instruções em Goiana, onde havia um convento das carmelitas desde o século XVII. Por conta das lacunas na documentação, “apenas se sabe que dentro de poucos anos ela estará dominando as línguas francesa e italiana, em condições de se oferecer como mestra de primeiras letras.” (DUARTE, 1995, p.19).

O primeiro livro escrito por Nísia Floresta foi Direitos das mulheres e injustiça dos homens, publicado quando ela tinha 22 anos. Naquela ocasião, ela vivia com Manuel Augusto de Faria 
O livro "Direitos das mulheres e injustiça dos homens” de Nísia Floresta: literatura, mulheres e o Brasil do século XIX

Rocha, estudante de Direito da Faculdade de Olinda, com quem teria três filhos. O pseudônimo escolhido revela sua personalidade e opções existenciais: Nísia é o diminutivo do seu nome; Floresta, o sítio onde ela nasceu (hoje, Nísia Floresta, uma cidade no Rio Grande do Norte); Brasileira, a afirmativa de seu nacionalismo, e Augusta, uma homenagem ao companheiro eleito.

No mesmo ano da primeira edição, a família segue de mudança para Porto Alegre, exceto seu irmão Joaquim Pinto Brasil, que fora admitido no curso de Direito, em Olinda. Muitos estudiosos sobre Nísia Floresta acreditam que ela sofria ameaças do primeiro marido, que, inconformado com o abandono e armado de razões jurídicas, estaria disposto a processá-la por adultério e abandono de lar (DUARTE, 1995, p.25). E, se foi esse mesmo o motivo da mudança repentina que a família fez para o sul do Brasil, em 1832, é difícil precisar.

As atitudes, escolhas e ideias de Nísia Floresta revelam a excepcionalidade desta mulher, e a enorme discrepância em relação ao comportamento e à condição característica de suas contemporâneas. Para Gilberto Freyre, Nísia Floresta foi “uma exceção escandalosa”:

\begin{abstract}
Verdadeira machona entre as sinhasinhas dengosas do meado do século XIX. No meio dos homens a dominarem sozinhos todas as atividades extra-domésticas, as próprias baronesas e viscondesas mal sabendo escrever, as senhoras mais finas soletrando apenas livros devotos e novelas [...], causa pasmo ver uma figura de Nísia (FREYRE, 1996, p.109).
\end{abstract}

Nesse ponto, é preciso considerar, além da identidade de gênero, a posição social e a identidade étnica que definiam as expectativas para as mulheres no Brasil do século XIX. Daí a importância de se avaliar, nas análises das relações de gênero, elementos como classe social e etnia/raça, conjuntamente. Conforme aponta a historiadora Joan Scott, embora haja certa falta de paridade entre esses elementos, suas sugestões são primordiais no que tange à utilização do gênero como categoria de análise:

Os(as) historiadores(as) devem, preferivelmente, examinar as maneiras como as identidades de gênero são realmente construídas e relacionar seus achados com toda uma série de atividades, organizações sociais e representações culturais historicamente situadas. (SCOTT, 1996, p. 11).

A presença da Corte desde 1808 foi minando a condição colonial do Brasil, na medida em que a imprensa foi inaugurada e as primeiras faculdades foram fundadas. Com a circulação de materiais impressos o país passou a ter efetivamente um mercado editorial: as salas de leitura, as 
reuniões públicas, os salões da elite letrada proporcionaram a entrada de ideias modernas e liberais no Brasil.

Quando teve início a Revolução Farroupilha, em 1835, Nísia Floresta vivia em Porto Alegre e era chefe de uma família composta por crianças e outras mulheres. O companheiro Augusto havia morrido em 1833; as mortes dele e dos pais de Nísia acorridas no mês de agosto, marcaram melancolicamente nossa autora, uma representante do Romantismo. A guerra civil no sul do Brasil cristalizou um ponto específico da crise entre identificações regionais e nacionais. Os meios urbanos eram mais voltados à causa legalista e sua imprensa representava predominantemente a classe média e, por esta razão, seu discurso pautava-se, também, na defesa do patrimônio. Os farroupilhas (e o próprio uso desse termo pejorativo pela historiografia) representavam certa ameaça à estabilidade dos lares, ao capital acumulado e aos benefícios da ‘civilização’ que a maior parte da elite descendente portuguesa desfrutava até então. Até por isso, a atuação de mulheres na guerra foi mais efetiva na defensiva legalista, protegendo suas propriedades e o status quo das suas famílias (BREWSTER, 2006).

Os conflitos foram usados para se estabelecer certo patriotismo. Em prol da estabilidade política e social, o período entre 1831 e 1845, ou seja, da abdicação de D. Pedro I ao fim da guerra civil no sul do país, foi um tempo de intensas disputas, quando um projeto de nação brasileira foi forjado pelo Império. Os farroupilhas não ofereceram ou articularam estratégias eficientes para a construção de uma identidade nacional: a República ficou restrita ao território sul. No Rio de Janeiro, a criação de entidades como o Colégio Pedro II e o Instituto Histórico e Geográfico Brasileiro (IHGB) foram marcos para a consolidação desse projeto.

Nísia Floresta permaneceu até 1837 em Porto Alegre, cidade tomada pelos farroupilhas, com os quais manteve vínculos. “Com certeza é deste período o início da propalada amizade de Nísia com Anita e Giuseppe Garibaldi, o italiano responsável em 1838 pelo comando geral da marinha da República Rio Grandense.” (DUARTE, 1995, p.28).

Certamente, a tensão da guerra contribuiu na sua decisão de mudar-se com a família para a Corte. Ela já atuara como educadora no nordeste e no sul do país, e no Rio de Janeiro inaugurou o Colégio Augusto, em 1838.

\section{Nísia Floresta educadora}

Como dona de escola e professora, Nísia Floresta defendeu suas posições educacionais em textos dedicados à temática feminina. No decorrer do ano de 1847, ela publicou três obras de caráter 
O livro "Direitos das mulheres e injustiça dos homens" de Nísia Floresta: literatura, mulheres e o Brasil do século XIX

pedagógico: Fany ou o modelo das donzelas; um breve texto de seis páginas intitulado Discurso que às suas educandas dirigiu Nísia Floresta Brasileira Augusta; e, ainda, Daciz ou a jovem completa, livro citado, mas não localizado pelos estudiosos de Nísia Floresta.

Entretanto, é no conteúdo do livro o Opúsculo Humanitário que podemos encontrar a síntese do pensamento de Nísia Floresta sobre a educação de meninas especificamente, mas também sobre o ensino de maneira geral. Nesse livro, por exemplo, a autora valeu-se de dados oficiais recentemente publicados para tecer duras críticas ao sistema de ensino, posicionando-se contrariamente ao governo sobre a falta de um direcionamento educacional, em específico sobre o ensino feminino. Ela analisa os dados divulgados no Quadro Demonstrativo do Estado da Instrução Primária e Secundária das Províncias do Império e do Município da Corte. E conhecendo a baixa quantidade de escolas para meninas, concluiu:

Acrescentemos agora ao medíocre número dessas escolas a confusão dos métodos, das doutrinas seguidas pelas professoras, quase sempre discordes em seus sistemas e, como já observamos, em grande parte sem as necessárias habilitações, e teremos, reduzido à expressão mais simples, o número da nossa população feminina que participa do ensino público e o grau de instrução que recebe. (FLORESTA, 1989b, p.83).

No Opúsculo Humanitário, além de tratar do fracasso do sistema geral de ensino, Nísia Floresta denunciava, sem citar nomes, as escolas da Corte comandadas por estrangeiros que, segundo ela, eram quase sempre despreparados para atuarem no ramo da educação. As críticas de Nísia Floresta caíam, também, sobre a educação que preparava as meninas meramente para atuarem nos salões.

Por volta dos anos 1820, o ensino feminino recebeu um novo impulso, já que o incremento da vida nos salões provocou mudanças significativas na educação das meninas da elite. Até então, sua alfabetização se restringia quase sempre à capacitação para uma leitura razoável de textos religiosos, além do estudo da língua pátria, da aritmética, da religião, do bordado e da costura. Aos moldes do patriarcalismo, a ignorância era uma forma de evitar a correspondência amorosa.

Às jovens mulheres eram dadas as incumbências, no âmbito privado, de bem-receber, ostentando habilidades ligadas às regras de etiqueta e à arte recreativa, mas também cumprindo o papel de colaboradoras dos pais, maridos ou irmãos para sua inserção ou permanência nos círculos sociais da elite urbana oitocentista (QUINTANEIRO, 1996). Além do canto, da dança e da música, o estudo do francês e da literatura instruíam as jovens para o mundo dos eventos sociais. 
Nísia Floresta conviveu com essa realidade quando comandou o Colégio Augusto (18381856) no Rio de Janeiro e, em seu Opúsculo, criticou a importância que os pais davam aos "triunfos que inebriam as filhas e lisonjeiam os pais," que inspiravam o "gosto por futilidades, as quais, dando-lhes apenas ligeiros matizes de boa educação, só lhes atraem passageiros sucessos.” (FLORESTA, 1989b, p.114-115).

De fato, sua proposta curricular incomodava. Ensinava-se latim no colégio Augusto, matéria considerada inadequada às meninas. Conforme mostra Constância Lima Duarte, o jornal $O$ Mercantil, de primeiro de janeiro de 1847, fez um comentário a propósito dos exames de línguas realizados no colégio de Nísia Floresta, que reflete as concepções sobre a educação das meninas daquele tempo: “Trabalhos de língua não faltaram; os de agulha ficaram no escuro. Os maridos precisam de mulher que trabalhe mais e fale menos.” (DUARTE, 1995, p.34).

As opiniões sobre o ensino dedicado às alunas do Colégio Augusto, publicadas quase sempre anonimamente nos jornais cariocas, apesar de terem tonalidade negativa, na verdade demonstram os avanços das propostas educacionais que destoavam da pedagogia em voga na época no que tange ao ensino feminino.

Esses e outros temas polêmicos, como a escravidão, por exemplo, foram abordados por Nísia Floresta em artigos que saíram na imprensa carioca e que foram compilados em livro sob o título de Opúsculo Humanitário, publicado em $1853^{2}$. O título do livro foi inspirado nos opúsculos de Auguste Comte, aliás, figura importante no pensamento nisiano.

\section{A experiência europeia e o positivismo}

O debate sobre o direito das mulheres passava necessariamente pelo movimento transatlântico de pessoas e ideias ao redor do mundo. Em meados dos anos 1850 o transporte no Atlântico contava com rotas marítimas comerciais, ligando as Américas ao Velho Mundo com uma frequência proporcional ao desenvolvimento tecnológico e à demanda de passageiros e mercadorias.

No final de 1849, acompanhada dos dois filhos, Nísia Floresta viajou pela primeira vez à Europa no que seria uma estada de pouco mais de um ano em Paris. Nesse período, ela frequentou as conferências ministradas por Auguste Comte sobre História Geral da Humanidade no Palais Cardinal, em Paris. No entanto, foi na segunda fase de vida europeia (1856-1872) que Nísia Floresta experimentou maior atividade intelectual.

Na efervescência parisiense ela conviveu com Auguste Comte, Lamartine e Alexandre Dumas (pai). Aliás, depois de envolver-se na guerra de unificação italiana ao lado de Garibaldi, Alexandre Dumas retornou a Paris e dedicou-se a palestras públicas que funcionavam como ponto 
O livro "Direitos das mulheres e injustiça dos homens" de Nísia Floresta: literatura, mulheres e o Brasil do século XIX

de encontro e espaço de divulgação de ideias. De fato, a cultura oral entre os letrados proporcionava convivências sociais importantes naquele século XIX. Os temas abordados nas palestras públicas entusiasmavam a plateia, demarcando posicionamentos e estabelecendo afinidades. Nísia Floresta dominava o francês, a língua prevalecente nos círculos frequentados por estrangeiros. Mulher de vida movimentada, ela viajou à Itália durante o processo de unificação. Esteve na Grécia e na Alemanha, inspirada pelos escritores românticos. Além da visita, publicou, em francês, suas experiências de viagem ${ }^{3}$.

Suas relações com o pai do positivismo se estreitaram quando o filósofo foi dispensado definitivamente da Escola Politécnica e passou a ser sustentado por amigos, como John Stuart Mill e Nísia Floresta. Por cerca de um ano, entre 1856 e 1857 eles trocaram cartas, e Comte enviava suas publicações a Nísia Floresta tecendo comentários sobre o positivismo. Em dezembro de 1856, Nísia Floresta enviou uma soma em dinheiro à sociedade positivista, pedindo seu anonimato. Da mesma forma invocou “a lembrança do anjo que teve, sobre sua vida, uma tão salutar influência, para lhe assegurar que nenhum outro coração no mundo lhe é mais simpático que o meu” (DUARTE, 2002, p. 73-74).

O anjo em questão é Clotilde de Vaux, figura que foi ‘divisor de águas’ na obra de Comte. A relação era platônica e ambos conviveram durante curto espaço de tempo. Morta precocemente em 1846, Clotilde de Vaux foi o gênio inspirador da nova religião. Em carta de agosto de 1856, Comte escreveu sobre o apreço que dedicava à Nísia Floresta e associou a brasileira com Clotilde de Vaux, a “Angélica Patrona a quem dediquei a minha obra capital.” (DUARTE, 2002, p. 67)

As cartas de Nísia Floresta e Auguste Comte revelam cordialidade, respeito intelectual e amizade. Entretanto, o filósofo esteve gravemente enfermo e, diante da sua recusa em se tratar, Nísia Floresta o aconselhou ao tratamento médico, evocando a figura do "anjo”, da "santa mulher.” (DUARTE, 2002, p.91) Na resposta Comte argumentou filosoficamente, afirmando que havia se emancipado da medicina, prevendo a cura de seus tumores e a regeneração da sua saúde sem ajuda médica. Sobre Clotilde, ele escreveu reticente: “A sua invocação de uma vítima angélica em apoio de um conselho perigoso, é tanto mais cega, quanto a minha Beatriz sucumbiu, não pela moléstia, mas pelos seus dois médicos.” Tratava-se de Clotilde de Vaux, chamada de Beatriz em referência a personagem de Dante (DUARTE, 2002, p. 94-95).

Em carta de 29 de agosto de 1857, Nísia Floresta dedicou um poema à Clotilde de Vaux, que sequer havia conhecido, exaltando as virtudes da musa comteana e fazendo coro ao positivismo. A resposta de Comte veio em agradecimento cordial, com um trecho de Petrarca seguido da frase: 
A sua tocante composição está irrevogavelmente colocada na gaveta sagrada que contém somente a correspondência excepcional. Respeito e simpatia. Auguste Comte, fundador da Religião Universal. Primeiro Pontífice da Humanidade. (DUARTE, 2002, p.100-101).

Uma semana depois, Auguste Comte morria vitimado pela doença que se recusou a tratar. Nísia Floresta foi uma das poucas mulheres que acompanharam o cortejo fúnebre.

No que tange à doutrina positivista, a mulher era o "sexo afetivo" e, em 1852, quando Comte concebeu o positivismo como religião da humanidade, escreveu em seu Catecismo:

O melhor resumo prático de todo o programa moderno breve consistirá neste princípio incontestável: o homem deve sustentar a mulher, a fim de que ela possa preencher convenientemente seu santo destino social. (COMTE, 1996, p.111).

A aproximação com o positivismo marcou o pensamento nisiano no que tange ao papel social das mulheres. Enquanto no livro Direitos das mulheres e injustiça dos homens havia a defesa da atuação das mulheres em postos de comando, no Opúsculo Humanitário a educação feminina deveria ser fator de elevação moral, importante para a instrução das mães de família e da sociedade. Conforme aponta Constância Lima Duarte:

A cultura geral, enfaticamente pleiteada, serviria tão somente para melhor preparar a mulher para assumir com responsabilidade o papel de mãe de família, dentro do rígido controle de sua moralidade. O "poder” feminino, tão sonhado anteriormente, limitar-se-ia àquele obtido através da influência junto aos filhos. (DUARTE, 1995, p.218)

As mulheres tinham um papel importante nos preceitos do positivismo, já que, dotadas de uma superioridade moral, seriam capazes de regenerar a sociedade em contraposição à rigidez e à racionalidade masculina. O princípio positivista não defendia a igualdade dos gêneros, pelo contrário, entendia as mulheres como figuras sociais importantes, dotadas de uma 'identidade positiva' fundamental na formação de uma nova sociedade. Seu lugar era atuando no âmbito privado.

Assim, após a primeira viagem à Europa, quando Nísia Floresta estabeleceu os primeiros contatos com o positivismo, suas ideias atribuíram às mulheres outras perspectivas quanto ao seu papel na sociedade. Vejamos o conteúdo do primeiro livro publicado por Nísia Floresta.

\section{A dita versão brasileira de Vindication}


O livro "Direitos das mulheres e injustiça dos homens" de Nísia Floresta: literatura, mulheres e o Brasil do século XIX

O livro Direitos das mulheres e injustiça dos homens foi considerado a tradução livre do Vindication de Mary Wollstonecraft até a publicação das pesquisas de Pallares-Burke. Tal informação foi repetida sem contestação, acatada pela história. No entanto, nos cerca de 150 anos que se seguiram a publicação de Nísia Floresta, a autora inglesa foi assimilada, também no Brasil, como principal defensora dos direitos das mulheres no decorrer do século XIX.

O texto publicado por Nísia Floresta foi dedicado às brasileiras e aos acadêmicos brasileiros. De suas “patrícias”, ela esperava que:

[...] longe de conceberdes qualquer sentimento de vaidade em vossos corações com a leitura deste pequeno livro, procureis ilustrar o vosso espírito com a de outros mais interessantes, unindo sempre a este proveitoso exercício a prática da virtude, a fim de que sobressaindo essas qualidades amáveis e naturais ao nosso sexo, que até o presente têm sido abatidas pela desprezível ignorância em que os homens, parece de propósito, têm nos conservado, eles reconheçam que o Céu nos há destinado para merecer na Sociedade uma mais alta consideração. (FLORESTA, 1989a, p.21).

Da mocidade acadêmica, “em quem a Nação tem depositado as mais belas esperanças”, ela almejava "que atendendo o estado a que nosso infeliz sexo tem sido injustamente condenado, privado das vantagens de uma boa educação [...] lamentareis a nossa sorte, pois que até em pequenas empresas não podemos desenvolver nossos talentos naturais”. (FLORESTA, 1989a, p.21)

No período que se seguiu à Independência, a elite intelectual brasileira empenhava-se na construção de um projeto de nação que se consolidou em instituições como o Colégio D. Pedro II e o IHGB, fundados em 1837. E é para essa elite intelectualizada que se dirige Nísia Floresta, de modo que podemos sugerir, observando os aspectos biográficos do autor de A Moreninha, que ela atingiu seu alvo: Joaquim Manuel de Macedo foi professor do colégio e membro ativo do instituto citados acima, além de deputado liberal e professor dos filhos de D. Pedro II (MORAES, 2004).

A terceira edição da versão brasileira de Vindication foi publicada em 1839, na capital do Império, e provavelmente tenha sido esse o livro conhecido por Macedo, que publicou A Moreninha cinco anos depois, aos 23 anos, quando também se formava em Medicina.

O texto 'clama’ os leitores homens à reflexão sobre a injusta condição das mulheres. Para tanto, em tom de desafio, a autora sugere que se valerá da razão para debater os costumes, que, inquestionáveis, contribuem para enraizar as diferenças sociais entre os sexos. Logo no primeiro capítulo Nísia Floresta escreve: 
Se cada homem, em particular, fosse obrigado a declarar o que sente a respeito de nosso sexo, encontraríamos todos de acordo em dizer que nós nascemos para seu uso, que não somos próprias senão para procriar e nutrir nossos filhos na infância, reger uma casa, servir, obedecer e aprazer aos nossos amos, isto é, a eles homens. (FLORESTA, 1989, p.35).

Valendo-se da visão utilitarista, seus argumentos são traçados no sentido de prover valor à atividade feminina de criação e cuidado dos filhos, da mesma forma que os homens são responsáveis pela geração dos filhos. Ela procura igualar tais funções para, em seguida, argumentar que "as mulheres, encarregando-se generosamente e sem interesse, do cuidado de educar os homens na sua infância, são as que mais contribuem para esta vantagem, logo são elas que merecem um maior grau de estima e respeito públicos.” (FLORESTA, 1989a, p.37).

Reunidos em sociedade, tributou-se aos homens as funções de príncipes, generais, soldados e jurisconsultos, pessoas úteis que partilham as fadigas do serviço público. É consenso, segundo o texto, que o respeito é proporcional a utilidade das pessoas: “Ora, sendo esta regra aplicável a todas as circunstâncias da vida, por que não devem ter as mulheres, mais que todos, direito à estima pública, contribuindo mais, sem comparação, a seu bem-estar?” (FLORESTA, 1989a, p.37).

Como uma herança do Iluminismo, a obra mais emblemática para o século XIX, no que tange ao papel social das mulheres, foi a novela Emílio, de Rousseau (1712-1778). No enredo, a educação da personagem Sophie deveria ser diferente em quantidade e qualidade. O produto final seria uma mulher-esposa que complementasse seu marido. Sua educação deveria ser modesta, prevenindo o marido do tédio, mas jamais desafiadora da intelectualidade dele. Com tal tradição, cresceram a literatura e o debate sobre a natureza da educação feminina. A educação da mulher centrava-se na preparação para seu destino 'natural' de esposa e mãe, e isso foi bastante explorado, principalmente no que tange ao seu papel na educação dos filhos, futuros cidadãos.

O texto de Direitos apresenta certa consonância com os preceitos acima, mas é justamente com base neles, ou seja, valendo-se da ideia de que a função social das mulheres era restrita ao casamento e à maternidade, que se seguem os argumentos subsequentes. Já que no capítulo seguinte questiona-se a superioridade masculina da razão e a pouca capacidade das mulheres para as ciências:

Todos sabem que a diferença dos sexos só é relativa ao corpo e não existe mais que nas partes propagadoras da espécie humana; porém, a alma que não concorre senão por sua união com o corpo, obra em tudo da mesma maneira sem atenção ao sexo. Nenhuma diferença existe entre a alma de um tolo e de um homem de espírito, ou de um ignorante e de um sábio, ou a de um menino de quatro anos e um homem de quarenta. Ora, como esta diferença não é maior entre as almas dos homens e a das mulheres, não se pode dizer que o corpo constitui alguma diferença real nas almas. 
O livro "Direitos das mulheres e injustiça dos homens" de Nísia Floresta: literatura, mulheres e o Brasil do século XIX

Toda sua diferença, pois, vem da educação, do exercício e da impressão dos objetos externos, que nos cercam nas diversas circunstâncias da vida. (FLORESTA, 1989a, p.47).

O texto de Nísia Floresta denunciava o absurdo que era considerar as ciências inúteis às mulheres. Sob o pretexto de que o estudo e as ciências tornariam as mulheres altivas e viciosas, "não pode ser, portanto, senão uma inveja baixa e indigna, que os induz a privar-nos das vantagens a que temos de um direito tão natural, como eles.” (FLORESTA, 1989a, p.49).

Procura-se traçar as causas da ausência das mulheres nos cargos públicos com base nos costumes e preconceitos que não eram questionados pelos homens: “[...] estão tão acostumados a ver as coisas tais quais agora são, que não podem imaginá-las de outra maneira.” (FLORESTA, 1989a, p.64). No rol de suas argumentações, as mulheres à frente do exército, administrando a justiça ou ensinando nas universidades seriam situações normais se a sociedade as considerasse como criaturas racionais.

Se em tempos imemoriais os homens tivessem sido menos invejosos e mais interessados em fazer justiça a nossos talentos, deixando-nos o direito de partilhar com eles dos empregos públicos, estariam tão acostumados em ver-nos preenchêlos, quanto estamos em os ver desonrá-los, e uma mulher, ou na roda dos Advogados, ou na Cadeira Magistral, não seria tão admirável como ver um Juiz grave, languidamente rendido ao lado de sua amante, ou um Lorde bordando um vestido para sua mulher. (FLORESTA, 1989a, p.65).

O tom panfletário percorre o texto todo e os títulos dos capítulos expressam sua principal reivindicação, qual seja, a igualdade dos gêneros no que tange à participação social das mulheres: “Se os homens são mais próprios que as mulheres para governar”, “Se as mulheres são ou não próprias a preencher os cargos públicos”, "Se as mulheres são naturalmente capazes de ensinar as ciências ou não” e “Se as mulheres são naturalmente próprias, ou não, para os empregos.” O texto de Direitos procura 'provar' a injustiça masculina em relação ao tratamento dado às mulheres. Em alguns trechos, seus argumentos beiram à arrogância:

Nosso sexo parece nascido para ensinar e praticar a medicina, para tornar a saúde aos doentes e a lhes conservar. $\mathrm{O}$ asseio, a prontidão e o cuidado fazem a metade de uma cura; e por este motivo os homens nos deviam adorar. (FLORESTA, 1989a, p.69).

Filósofos e teólogos são criticados sem a citação de nomes. Se oportunidades fossem dadas às mulheres, “não faríamos como certos homens, que empregam anos inteiros e algumas vezes 
mesmo toda sua vida, a raciocinar sobre entes de razão e bagatelas imaginárias, que só existem em seus próprios cérebros.” (FLORESTA, 1989a, p.70). Da mesma forma, mulheres exemplares são citadas, tais como Safo, Cornélia, Clara Schumann, rainha Elizabeth, figuras da Antiguidade, entre outras, cujas ações exemplificam atitudes dignas em defesa das mulheres.

No último capítulo, defende-se a participação das mulheres na guerra, seja como comandante de campanhas militares, seja como combatente. Valendo-se disso, questiona-se:

Não há entre as mulheres diferentes graus de força, assim como entre os homens? Não se encontram fortes e fracos em ambos os sexos? Os homens educados na ociosidade e na moleza são mais fracos que as mulheres; estas, endurecidas pela necessidade são freqüentemente mais fortes do que eles. (FLORESTA, 1989a, p.80).

O texto de Nísia Floresta protesta quanto ao uso recorrente, “no modo ordinário de falar”, de termos como "afeminado”, quando se faz referência à falta de coragem de um homem, assim como quando se exalta uma mulher dizendo-se, “é um homem.” Ela procura argumentar, e até cita exemplos, de que mais ou menos força ou robustez, não interfere na dignidade e nem na superioridade das ações que levam às vitórias militares.

A causa da temeridade tida como nata ao sexo feminino, estava na maneira como as mulheres são educadas, que as autoriza a toda sorte de temor. E questiona: "Pode-se pois imputar o nosso medo à falta de coragem?” (FLORESTA, 1989a, p.84).

O texto de Direitos argumenta numa sequência racional e linear, trata das crenças do passado, como o Geocentrismo e refere-se a Descartes. (FLORESTA, 1989a, p.29). O matiz é iluminista. E não poderia ser diferente, conforme descobriu Pallares-Burke, já que se tratava de um texto popularizado no período iluminista por Sophie, pseudônimo de Mary Montagu ou ainda, escrito por Poulan de La Barre no século XVII.

O texto brasileiro afirma que não pretendia revoltar as mulheres contra os homens, visto que o original inglês se vale da palavra REVOLUTION na conclusão do livro, assim mesmo, em letras garrafais. Mesmo que Wollstonecraft tenha usado tal palavra contra as maneiras fúteis e viciosas da sociedade típica do período, criticando os costumes femininos e as coquetes dos salões. (WOLLSTONECRAFT, 1792, p.216).

O tom revolucionário dos Direitos está na defesa da participação efetiva das mulheres em cargos públicos e postos de comando. Refere-se às noções gerais dos gêneros no século das Luzes, num período em que as mulheres eram consideradas incapazes de exercer suas funções intelectuais. A maior ousadia do livro está em pleitear postos de trabalho e no governo, ou seja, o acesso das 
O livro "Direitos das mulheres e injustiça dos homens” de Nísia Floresta: literatura, mulheres e o Brasil do século XIX

mulheres ao espaço público. Entretanto, Nísia Floresta não sustenta esse mesmo discurso no livro Opúsculo Humanitário, conforme analisado.

\section{A título de conclusão}

O Brasil do século XIX era uma sociedade escravocrata e patriarcal. A escravidão se encarregava da manutenção da mão de obra nas lavouras, nas residências, nas cidades; negros alforriados possuíam escravos e podiam alugar essa mão de obra. As mulheres brancas da elite urbana se europeizavam; as negras eram amas de leite; outras tantas mulheres pobres ou alforriadas vendiam os frutos do seu trabalho, atuando como quitandeiras ou vendedoras e, por isso, transitavam mais frequentemente no espaço público do que as mulheres da elite.

Nísia Floresta não cumpriu exclusivamente as expectativas sociais típicas das famílias proprietárias de terras no nordeste. Rebelou-se das convenções, enfim. Depois da morte do companheiro, como viúva, certamente esse estado civil proporcionou à Nísia Floresta acesso a âmbitos comumente negados às mulheres de sua classe que eram solteiras ou casadas, já que dependiam socialmente dos pais ou maridos.

Depois da sua experiência no Velho Mundo, suas ideias sobre as expectativas sociais das mulheres sofreram influências do Positivismo, então Nísia Floresta adquiriu posicionamentos diferentes do tom panfletário contido no seu primeiro livro. Aliás, o Direitos das mulheres $e$ injustiça dos homens não era genuinamente de sua autoria e sequer a tradução do Vindication de Mary Wollstonecraft, apesar dessa informação ter se perpetuado na historiografia e contribuído para a identificação de Nísia Floresta como precursora do feminismo no Brasil.

Entretanto, seu primeiro livro contribuiu para que o nome da autora inglesa fosse assimilado ao rol dos defensores dos direitos das mulheres também no Brasil, no decorrer do século XIX.

\section{Notas:}

\footnotetext{
${ }^{1}$ A primeira edição e anterior a essa foi publicada em Paris, em 1878.

${ }^{2}$ A segunda edição do livro foi publicada 136 anos depois, ou seja, em 1989, com estudo introdutório e notas de Peggy Sharppe-Valadares.

${ }^{3}$ Itinerário de uma viagem à Alemanha. Florianópolis: Santa Cruz do Sul, RS: Editora Mulheres, EDUNISC, 1998, foi publicado no Brasil 141 anos depois da edição francesa (1857). Da mesma editora, Cintilações de uma alma brasileira, originariamente publicado na Itália, em 1859, chegou em edição brasileira em 1997. Três anos na Itália seguidos de uma viagem à Grécia que possui datas duvidosas quanto à publicação da primeira edição em Paris (1861 ou 1864), mas que só chegou a ser publicado no Brasil em 1998 (Natal: EDUFRN).
} 


\section{Referência:}

BONACCHI, G.; GROPPI, A. (Org.) O dilema da cidadania: direitos e deveres das mulheres. São Paulo: Editora Unesp, 1995.

BREWSTER, C.; DAVIES, C.; OWEN, H. South American independence: gender, politics, text. Liverpool: Univ. Press, 2006.

COMTE, A. Curso de filosofia positivista: discurso preliminar sobre o conjunto do positivismo. Trad. José A. Giannotti e Miguel Lemos. São Paulo: Editora Nova Cultural, 1996.

DIETHE, C. Towards emancipation: German women writers of the nineteenth century. New York: Berghanhn Books, 1998.

DUARTE, C. L. Nísia Floresta: vida e obra. Natal: Editora Universitária/UFRN, 1995.

(Org.). Cartas: Nísia Floresta e Auguste Comte. Florianópolis: Edusc, 2002.

. Nísia Floresta: a primeira feminista do Brasil. Florianópolis: Editora Mulheres, 2005.

FLORESTA, N. Direitos das mulheres e injustiça dos homens. São Paulo: Editora Cortez, 1989a.

. Opúsculo Humanitário. São Paulo: Editora Cortez, 1989b.

. Fragmentos de uma obra inédita: notas biográficas. Brasília: Editora da UnB, 2001.

KOSTER, H. Viagens ao nordeste do Brasil: Travels in Brazil. Tradução e notas de Luiz da Câmara Cascudo. Rio de Janeiro: Companhia Editora Nacional, 1942.

MACEDO, J. J. de. A Moreninha. Disponível em:

$<$ http://www.dominiopublico.gov.br/download/texto/bn000008.pdf > . Acesso em: abr. 2011.

MORAES, D. Z. A ‘tagarelice’ de Macedo e o ensino de história do Brasil. História, São Paulo, n. 23 (1-2), p. 85-107, 2004.

MOREIRA LEITE, M. L. A condição feminina no Rio de Janeiro, século XIX: antologia de textos de viajantes estrangeiros. São Paulo: Hucitec, 1984.

PALLARES-BURKE, M. L. G. Nísia Floresta, o carapuceiro e outros ensaios de tradição cultural. São Paulo: Editora Hucitec, 1996.

PIEPKE, S. L. Mathilde Franziska Anneke (1817-1884): the works and life of a German-American activist. New York: Peter Lang Publishing, 2006.

QUINTANEIRO, T. Retrato de mulher: O cotidiano feminino no Brasil sob o olhar de viageiros do século XIX. Petrópolis: Vozes, 1996.

SCOTT, J. Gênero: uma categoria útil para a análise histórica. In: SOS CORPO: gênero e cidadania. Tradução de Cristine Rufino Dabat e Maria Betânia Ávila. 3.ed. Recife, abril de 1996. 
O livro "Direitos das mulheres e injustiça dos homens" de Nísia Floresta: literatura, mulheres e o Brasil do século XIX

TELLES, N. Escritoras, escritas, escrituras. In: DEL PRIORI, M. (Org.) História das mulheres no Brasil. São Paulo: Contexto, 1997. p. 401-442.

WOLLSTONECRAFT, M. A Vindication of the rights of woman. Disponível em:

$<$ https://scholarsbank.uoregon.edu/xmlui/bitstream/handle/1794/785/vindication.pdf?sequence=1 $>$. Acesso em: jul. 2011.

Recebido em 30/08/2011

Aprovado em 11/10/2011. 